\title{
The sensitivities of emissions reductions for the mitigation of UK PM 2.5
}

\author{
M. Vieno ${ }^{1}$, M. R. Heal ${ }^{2}$, M. L. Williams ${ }^{3}$, E. J. Carnell ${ }^{1}$, E. Nemitz ${ }^{1}$, J. R. Stedman ${ }^{4}$, and S. Reis ${ }^{1,5}$ \\ ${ }^{1}$ Natural Environment Research Council, Centre for Ecology \& Hydrology, Penicuik, UK \\ ${ }^{2}$ School of Chemistry, The University of Edinburgh, Edinburgh, UK \\ ${ }^{3}$ Environmental Research Group, Kings College London, London, UK \\ ${ }^{4}$ Ricardo-AEA, Harwell, UK \\ ${ }^{5}$ University of Exeter Medical School, Knowledge Spa, Truro, UK
}

Correspondence to: M. Vieno (vieno.massimo@gmail.com)

Received: 12 June 2015 - Published in Atmos. Chem. Phys. Discuss.: 5 August 2015

Revised: 20 November 2015 - Accepted: 7 December 2015 - Published: 18 January 2016

\begin{abstract}
The reduction of ambient concentrations of fine particulate matter $\left(\mathrm{PM}_{2.5}\right)$ is a key objective for air pollution control policies in the UK and elsewhere. Long-term exposure to $\mathrm{PM}_{2.5}$ has been identified as a major contributor to adverse human health effects in epidemiological studies and underpins ambient $\mathrm{PM}_{2.5}$ legislation. As a range of emission sources and atmospheric chemistry transport processes contribute to $\mathrm{PM}_{2.5}$ concentrations, atmospheric chemistry transport models are an essential tool to assess emissions control effectiveness. The EMEP4UK atmospheric chemistry transport model was used to investigate the impact of reductions in $\mathrm{UK}$ anthropogenic emissions of primary $\mathrm{PM}_{2.5}, \mathrm{NH}_{3}$, $\mathrm{NO}_{x}, \mathrm{SO}_{x}$ or non-methane VOC on surface concentrations of $\mathrm{PM}_{2.5}$ in the UK for a recent year (2010) and for a future current legislation emission (CLE) scenario (2030). In general, the sensitivity to UK mitigation is rather small. A $30 \%$ reduction in UK emissions of any one of the above components yields (for the 2010 simulation) a maximum reduction in $\mathrm{PM}_{2.5}$ in any given location of $\sim 0.6 \mu \mathrm{g} \mathrm{m}^{-3}$ (equivalent to $\sim 6 \%$ of the modelled $\mathrm{PM}_{2.5}$ ). On average across the UK, the sensitivity of $\mathrm{PM}_{2.5}$ concentrations to a $30 \%$ reduction in UK emissions of individual contributing components, for both the 2010 and 2030 CLE baselines, increases in the order $\mathrm{NMVOC}, \mathrm{NO}_{x}, \mathrm{SO}_{x}, \mathrm{NH}_{3}$ and primary $\mathrm{PM}_{2.5}$; however there are strong spatial differences in the $\mathrm{PM}_{2.5}$ sensitivities across the UK. Consequently, the sensitivity of $\mathrm{PM}_{2.5}$ to individual component emissions reductions varies between area and population weighting. Reductions in $\mathrm{NH}_{3}$ have the greatest effect on area-weighted $\mathrm{PM}_{2.5}$. A full UK population
\end{abstract}

weighting places greater emphasis on reductions of primary $\mathrm{PM}_{2.5}$ emissions, which is simulated to be the most effective single-component control on $\mathrm{PM}_{2.5}$ for the 2030 scenario. An important conclusion is that weighting corresponding to the average exposure indicator metric (using data from the 45 model grids containing a monitor whose measurements are used to calculate the UK AEI) further increases the emphasis on the effectiveness of primary $\mathrm{PM}_{2.5}$ emissions reductions (and of $\mathrm{NO}_{x}$ emissions reductions) relative to the effectiveness of $\mathrm{NH}_{3}$ emissions reductions. Reductions in primary $\mathrm{PM}_{2.5}$ have the largest impact on the AEI in both 2010 and the 2030 CLE scenario. The summation of the modelled reductions to the $\mathrm{UK} \mathrm{PM}_{2.5}$ AEI from $30 \%$ reductions in UK emissions of primary $\mathrm{PM}_{2.5}, \mathrm{NH}_{3}, \mathrm{SO}_{x}, \mathrm{NO}_{x}$ and VOC to-

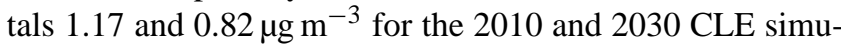
lations, respectively (not accounting for non-linearity).

\section{Introduction}

Atmospheric particulate matter (PM) has a range of adverse impacts including on climate change through radiative forcing (IPCC, 2013) and on human health (WHO, 2006, 2013). The global health burden from exposure to groundlevel ambient fine particulate matter (as characterized by the $\mathrm{PM}_{2.5}$ metric) is substantial. The Global Burden of Disease project attributed 3.2 million premature deaths and 76 million disability-adjusted life years to exposure to ambient $\mathrm{PM}_{2.5}$ concentrations prevailing in 2005 (Lim et al., 2012). 
Exposure to ambient $\mathrm{PM}_{2.5}$ remains a major health issue in Europe. The European Environment Agency report that for the period $2010-2012,10-14 \%$ of the urban population in the EU28 countries were exposed to ambient concentrations of $\mathrm{PM}_{2.5}$ exceeding the $\mathrm{EU}$ annual-average $\mathrm{PM}_{2.5}$ reference value of $25 \mu \mathrm{g} \mathrm{m}{ }^{-3}$, but $91-93 \%$ were exposed to concentrations exceeding the WHO annual-average $\mathrm{PM}_{2.5}$ air quality guideline of $10 \mu \mathrm{g} \mathrm{m}^{-3}$ (EEA, 2014).

European Commission (EC) legislation for $\mathrm{PM}_{2.5}$ includes an obligation on individual member states to reduce exposure to $\mathrm{PM}_{2.5}$ in areas of population by a prescribed percentage between 2010 and 2020. The exposure to $\mathrm{PM}_{2.5}$ is quantified through the average exposure indicator (AEI) which is the average of the annual $\mathrm{PM}_{2.5}$ measured across designated urban background and suburban sites spread over cities and large towns (averaged over the 3-year periods spanning 2010 and 2020). The AEI is therefore a quasi-indicator of population-weighted $\mathrm{PM}_{2.5}$. For the UK, the calculation of the AEI uses data from 45 sites (Brookes et al., 2012) and the required reduction by 2020 is $15 \%$ from its 2010 value of $13 \mu \mathrm{g} \mathrm{m}^{-3}$ (Defra, 2012).

While standards focus on $\mathrm{PM}_{2.5}$ mass concentrations, meeting these standards is complicated by the considerable chemical heterogeneity, which arises because ambient $\mathrm{PM}_{2.5}$ comprises both primary PM emissions and secondary inorganic and organic components formed within the atmosphere from gaseous precursor emissions, specifically $\mathrm{NH}_{3}$, $\mathrm{NO}_{x}\left(\mathrm{NO}\right.$ and $\left.\mathrm{NO}_{2}\right), \mathrm{SO}_{2}$, and a wide range of non-methane volatile organic compounds (VOC) (USEPA, 2009; AQEG, 2015). Meteorological conditions also control $\mathrm{PM}_{2.5}$ concentrations through their influences on dispersion, chemistry, and deposition.

European legislation sets current and future caps on anthropogenic emissions of primary and secondary-precursor components of $\mathrm{PM}_{2.5}$ at national level and from individual sources (Heal et al., 2012). Although it is well-known that much of the ambient $\mathrm{PM}_{2.5}$ in the UK derives from transboundary emissions and transport into the UK (Vieno et al., 2014; AQEG, 2015), a pertinent policy question to address is what additional surface $\mathrm{PM}_{2.5}$ reductions could the UK unilaterally achieve, at least in principle? In other words, what are the sensitivities of UK $\mathrm{PM}_{2.5}$ to UK reductions in emissions of relevant components?

This is the motivation for the work presented here, which investigates the impact of reductions from UK anthropogenic sources of emissions of primary $\mathrm{PM}_{2.5}$ and of precursors of secondary $\mathrm{PM}_{2.5}$ on surface $\mathrm{PM}_{2.5}$ concentrations across the whole UK. To adequately simulate the UK national domain requires the use of a regional atmospheric chemistry transport model (ACTM), in this study the EMEP4UK Eulerian ACTM (Vieno et al., 2009, 2010, 2014). Recognizing that reductions in UK and rest-of-Europe emissions are already projected under current legislation, this work compares the present-day sensitivity of UK emissions reductions on UK $\mathrm{PM}_{2.5}$ with a future time point (2030) to examine the effec- tiveness of potential options in the future. It is recognized that climate change may also have some influence on future $\mathrm{PM}_{2.5}$ concentrations in the UK; however the focus is here on UK precursor emission sensitivity and many studies have concluded that on the 2030 timescale air pollutant concentrations will be much more strongly influenced by changes in precursor emissions than by changes in climate (e.g. Langner et al., 2012; Coleman et al., 2013; Colette et al., 2013).

Throughout, the focus is on annual average $\mathrm{PM}_{2.5}$, since this is the metric within the AEI, which in turn is driven by the evidence from epidemiological studies that demonstrate associations between adverse health outcomes and long-term (annual average) concentrations of $\mathrm{PM}_{2.5}$ (COMEAP, 2010; WHO, 2013). It is also recognized that, whilst the focus here is on reduction in concentrations of $\mathrm{PM}_{2.5}$ from the perspective of its impact on human health, the reduction of anthropogenic emissions in general will also have other benefits including on human health, on $\mathrm{N}$ and $\mathrm{S}$ deposition, and on ozone formation.

\section{Methods}

\subsection{Model description and set-up}

The EMEP4UK model used here is a regional ACTM based on version rv4.4 (www.emep.int) of the EMEP MSC-W model which is described in Simpson et al. (2012). A detailed description of the EMEP4UK model is given in Vieno et al. (2010, 2014).

The EMEP4UK model meteorological driver is the Weather Research and Forecast (WRF) model version 3.1.1 (www.wrf-model.org). The EMEP4UK and WRF model horizontal resolution is $50 \mathrm{~km} \times 50 \mathrm{~km}$ for the extended European domain and $5 \mathrm{~km} \times 5 \mathrm{~km}$ for the inner domain as illustrated in Fig. 1. The EMEP4UK model uses a nested approach, the European domain concentrations are used as boundary condition for the UK domain. The boundary conditions at the edge of the European domain are prescribed concentrations in terms of latitude and adjusted for each year. For ozone, 3-D fields for the whole domain are specified from climatological ozone-sonde data sets, modified monthly against clean-air surface observations as described in Simpson et al. (2012).

The default EMEP MSC-W chemical scheme was used for the present study, as it has been extensively validated at the European scale (Simpson et al., 2012, www.emep.int). The scheme has 72 species and 137 reactions, and full details are given in Simpson et al. (2012). The gas/aerosol partitioning is the model for aerosols reacting system (MARS) formulation (Simpson et al., 2012). In the model version used here, $\mathrm{PM}_{2.5}$ is the sum of the fine $\left(\mathrm{PM}_{2.5}\right)$ fraction of ammonium $\left(\mathrm{NH}_{4}^{+}\right)$, sulphate $\left(\mathrm{SO}_{4}^{2-}\right)$, nitrate $\left(\mathrm{NO}_{3}^{-}\right)$, elemental carbon (EC), organic matter (OM), sea salt (SS), mineral dust, and 

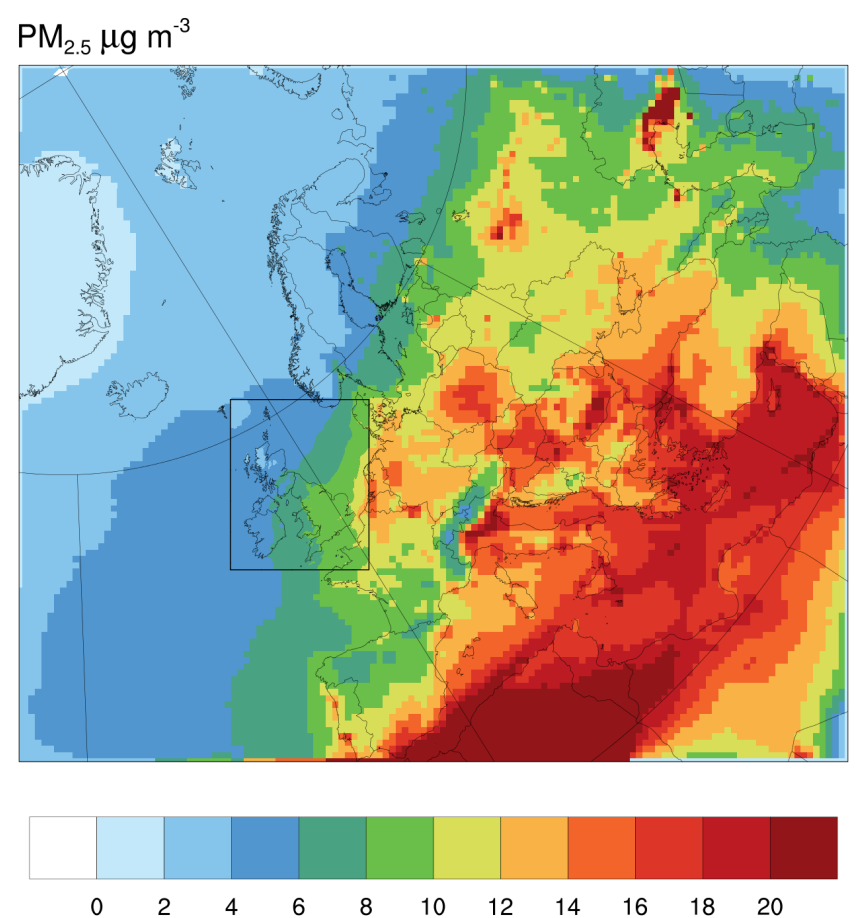

Figure 1. 2010 EMEP4UK annual-average surface concentrations of $\mathrm{PM}_{2.5}\left(\mu \mathrm{g} \mathrm{m}^{-3}\right)$ at $50 \mathrm{~km} \times 50 \mathrm{~km}$ horizontal resolution for the European model domain, and at $5 \mathrm{~km} \times 5 \mathrm{~km}$ horizontal resolution for the nested Great Britain and Ireland domain (black box).

$27 \%$ of the coarse nitrate. $\mathrm{PM}_{10}$ is the sum of $\mathrm{PM}_{2.5}$ plus the coarse $\left(\mathrm{PM}_{2.5-10}\right)$ fraction of $\mathrm{EC}, \mathrm{OM}, \mathrm{NO}_{3}^{-}$, SS, and dust.

Whilst fine nitrate production is modelled using a thermodynamic model (MARS), the formation of coarse nitrate from nitric acid $\left(\mathrm{HNO}_{3}\right)$ uses a parameterized approach that seeks to capture the $\mathrm{HNO}_{3}$ reaction with sea salt and crustal material. The conversion rate of $\mathrm{HNO}_{3}$ to coarse nitrate depends on relative humidity, as described by Simpson et al. (2012), but is not explicitly linked to the surface area of the existing coarse aerosol. Both nitrate generation mechanisms compete for the same $\mathrm{HNO}_{3}$, and whilst this constrains the total amount of nitrate produced, it is acknowledged that the resulting split into fine and coarse nitrate is somewhat uncertain as discussed in Aas et al. (2012). A more explicit aerosol scheme is under development for the model.

Anthropogenic emissions of $\mathrm{NO}_{x}, \mathrm{NH}_{3}, \mathrm{SO}_{2}$, primary $\mathrm{PM}_{2.5}$, primary $\mathrm{PM}_{\text {coarse }}, \mathrm{CO}$, and non-methane VOC for the UK are derived from the National Atmospheric Emission Inventory (NAEI, http://naei.defra.gov.uk) at $1 \mathrm{~km} \times 1 \mathrm{~km}$ resolution and aggregated to $5 \mathrm{~km} \times 5 \mathrm{~km}$ resolution. For the European domain, the model uses the EMEP $50 \mathrm{~km} \times 50 \mathrm{~km}$ resolution emission estimates provided by the Centre for Emission Inventories and Projections (CEIP, http://www. ceip.at/). Shipping emissions estimates, for the inner domain, are derived from the ENTEC (now Amec Foster Wheeler) emissions estimate (ENTEC, 2010). Natural emissions of isoprene and DMS are as described in Simpson et al. (2012).

The EMEP MSC-W model from which the EMEP4UK model is derived is used widely in support of European air quality science and policy development and the performances of both have been extensively evaluated (Carslaw, 2011b; Schulz et al., 2013; Simpson et al., 2014; Schaap et al., 2015).

\subsection{Model experiments}

A base run and a set of 5 sensitivity experiments were carried out for emissions and meteorology for 2010. The experiments applied $30 \%$ reductions to UK anthropogenic emissions from all sectors for each of the following pollutants individually: primary $\mathrm{PM}_{2.5}, \mathrm{NH}_{3}, \mathrm{NO}_{x}, \mathrm{SO}_{x}$ and NMVOC. This $30 \%$ perturbation was applied to land-based emissions only; shipping emissions (both domestic and international) were left unchanged.

Model runs were repeated for a 2030 future emissions scenario to investigate sensitivities of UK $\mathrm{PM}_{2.5}$ to UK emissions reductions further along the pathway of current legislation (CLE) emissions. The 2030 CLE emissions used in the model runs were based on the 2030 IIASA CLE projection (IIASA, 2012) for Europe and the Updated Energy Projections (UEP, version 45) for the UK. The UEPs are developed and regularly updated by analysing and projecting future energy use and are based on assumptions of future economic growth, fossil fuel prices, UK population development, and other key variables. A set of projections is based on a range of assumptions to represent the uncertainty in making such projections into the future. For this manuscript, the mid-range estimates were used. For a full description of the UEPs and the methodology for their compilation, see DECC (2015). Emissions from shipping were 2020 emissions estimate provided by ENTEC (now Amec Foster Wheeler) (ENTEC, 2010).

No change in the spatial distribution of emissions was made. Whilst there will likely be some changes in the spatial distribution of emissions, such changes are not easily predicted for a future scenario, and may be anticipated to be smaller than the changes in absolute amounts of emissions. The boundary and initial conditions for ozone and particles outside the European domain were left unchanged to the year 2010 , as was the meteorology. The use of the same meteorology isolates the sensitivity of surface $\mathrm{PM}_{2.5}$ to emissions reductions at some future date from the effects on surface $\mathrm{PM}_{2.5}$ due to differences in meteorology.

As well as maps of annual-average surface $\mathrm{PM}_{2.5}$ concentrations the following three summary statistics for $\mathrm{UK} \mathrm{PM}_{2.5}$ were calculated: (i) the area-weighted average, i.e. the average of all $5 \mathrm{~km} \times 5 \mathrm{~km}$ model grids over the UK; (ii) the population-weighted average, i.e. the $5 \mathrm{~km} \times 5 \mathrm{~km}$ gridded estimates of $\mathrm{PM}_{2.5}$ surface concentrations re-projected onto the British National Grid and multiplied by population es- 


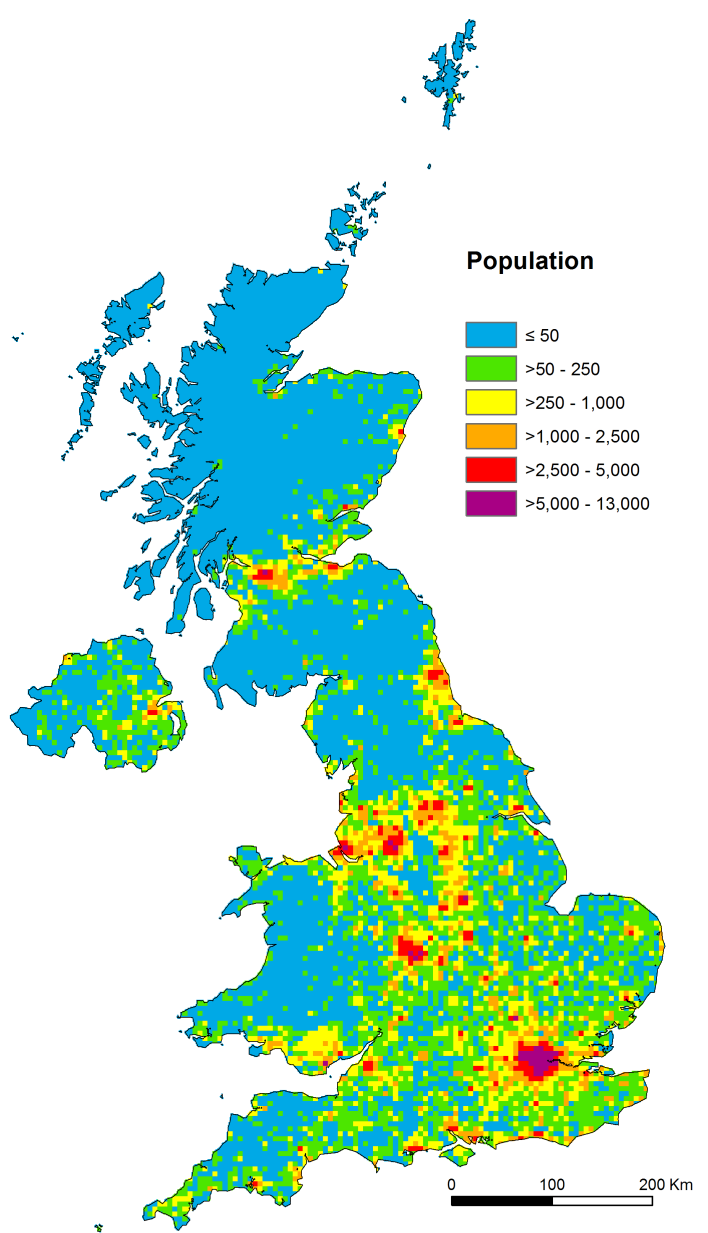

Figure 2. Gridded UK population density based on the UK census at the $5 \mathrm{~km} \times 5 \mathrm{~km}$ grid spatial resolution. Units are population $\mathrm{km}^{-2}$.

timates at the same spatial resolution (derived from the UK census, http://census.edina.ac.uk/) (Fig. 2) and divided by the sum of the UK population; (iii) a value analogous to the average exposure indicator (AEI), calculated as the average of the concentrations for the 45 model grids containing a $\mathrm{PM}_{2.5}$ monitor whose measurements are used to define the UK's 2010 AEI value (Brookes et al., 2012).

\section{Results}

Example comparisons between EMEP4UK-modelled surface concentrations of $\mathrm{PM}_{2.5}$ components and total measured $\mathrm{PM}_{2.5}$ are shown in Fig. 3 for three UK national network monitoring sites: Edinburgh St. Leonards, an urban background site in the north of the UK; London North Kensington, an urban background site in central London in the south-east of the UK; and Harwell, a rural background site in central England. Monthly averages of the hourly measured and modelled data are presented. Model simulations follow
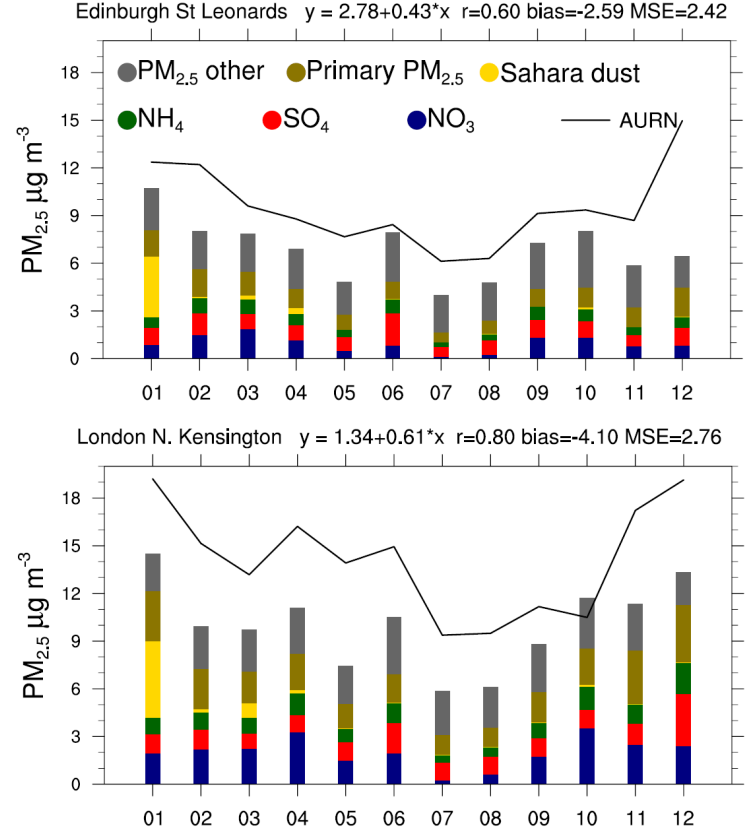

Harwell $y=0.20+0.87^{*} \times \quad r=0.94$ bias $=-1.13$ MSE $=1.01$

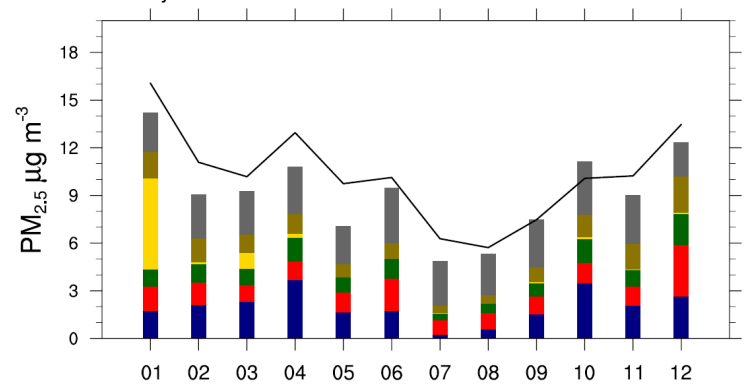

Figure 3. 2010 monthly-averaged EMEP4UK simulated $\mathrm{PM}_{2.5}$ components and total $\mathrm{PM}_{2.5}$ observations by TEOM-FDMS at the Edinburgh St. Leonards, London North Kensington and Harwell UK national network (AURN) monitoring sites. Both the modelled and observed data are averaged from hourly values. The linear regression between the monthly averaged observation and model is also shown at the top of each panel, along with the correlation coefficient, $r$, bias and mean square error.

the observational time trends well. The model simulations of the SIA components $\mathrm{SO}_{4}^{2-}, \mathrm{NO}_{3}^{-}$, and $\mathrm{NH}_{4}^{+}$have previously been individually evaluated by Vieno et al. (2014) against 10 years of speciated observations made at $\sim 30$ sites across the UK in the AGANET network (Conolly et al., 2011). The four UK sites included in Vieno et al. (2014) showed good agreement between the monthly averaged EMEP4UK simulation and the observed $\mathrm{NO}_{3}^{-}$and $\mathrm{SO}_{4}^{2-}$, with a bias range of 0.28 to -0.62 and 0.8 to $-0.27 \mu \mathrm{g} \mathrm{m}^{-3}$, respectively. The EMEP4UK model was also evaluated against observations and other models in a UK model inter-comparison organized by the UK Department for Environment, Food \& Rural Affairs (Defra) (Carslaw, 2011a, b). The persistent negative bias in the sum of the modelled $\mathrm{PM}_{2.5}$ against observation in 


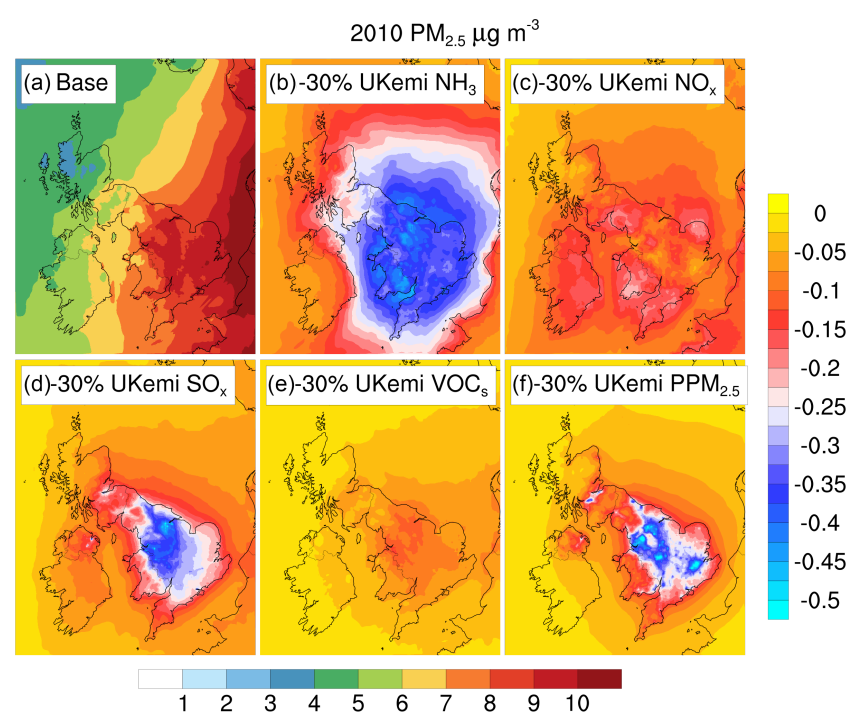

Figure 4. Model simulations of the impact of $30 \%$ UK emissions reductions on annual-average surface concentration of $\mathrm{PM}_{2.5}$. Panel (a) 2010 base-case scenario, no emissions reduction (bottom colour scale); remaining panels, the change in annual-average $\mathrm{PM}_{2.5}$ for $30 \% \mathrm{UK}$ emissions reductions in (b) $\mathrm{NH}_{3}$, (c) $\mathrm{NO}_{x}$, (d) $\mathrm{SO}_{x}$, (e) VOC, and (f) primary $\mathrm{PM}_{2.5}$ (right colour scale). All units are $\mu \mathrm{g} \mathrm{m}^{-3}$.

Fig. 3 is consistent with the absence of re-suspended dust in the model configuration used here, and possibly also reflects a difference in the treatment of particle-bound water in model and measurement. The omission of re-suspended dust does not impact on the investigations here of the sensitivities of $\mathrm{PM}_{2.5}$ concentrations to anthropogenic emissions reductions; however it is acknowledged that since particle-bound water is related to the mass of secondary inorganic components its omission will have some impact on the sensitivity of $\mathrm{PM}_{2.5}$ to inorganic precursor gas emissions reductions. Different measurement techniques and conditions incorporate different proportions of the ambient $\mathrm{PM}_{2.5}$ water content. We focus here on changes to the dry mass concentrations of surface $\mathrm{PM}_{2.5}$ derived from changes in the emissions of primary $\mathrm{PM}_{2.5}$ and secondary $\mathrm{PM}_{2.5}$ precursor gases. (It is also noted that values of relative reductions in modelled $\mathrm{PM}_{2.5}$ will be slightly higher than if expressed relative to measured $\mathrm{PM}_{2.5}$ at that location). Some model underestimation may also derive from dilution of primary $\mathrm{PM}_{2.5}$ emissions into the $5 \mathrm{~km}$ grid of the model compared with the primary emissions more local to an urban background monitor.

The simulated "baseline" 2010 annual-average surface concentrations for $\mathrm{PM}_{2.5}$ at $50 \mathrm{~km}$ horizontal resolution for the EMEP4UK European domain and for the nested $5 \mathrm{~km}$ horizontal resolution Great Britain and Ireland domain are shown in Fig. 1. The UK 2010 annual-average surface concentrations of $\mathrm{PM}_{2.5}$ are generally lower compared with neighbouring continental countries such as France, the

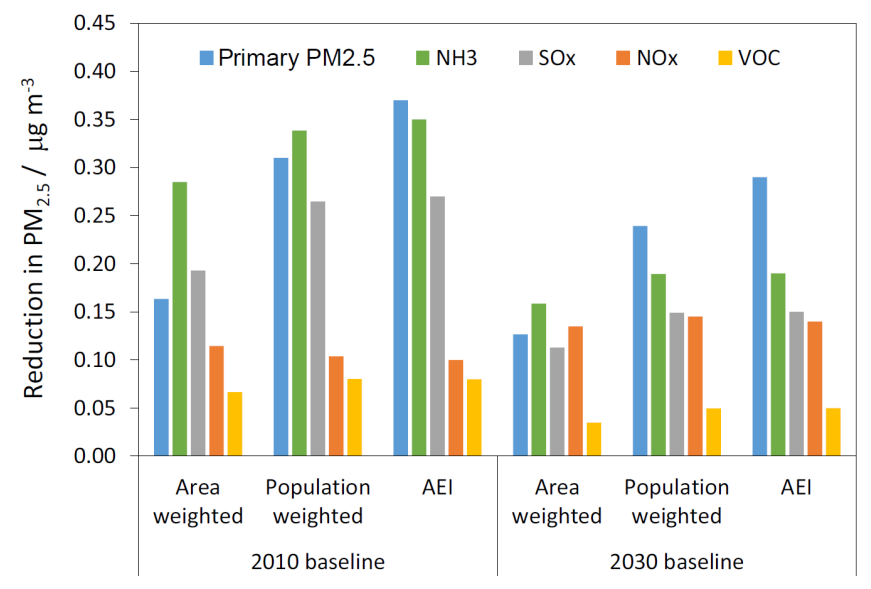

Figure 5. The impact of $30 \%$ UK terrestrial emissions reductions in primary $\mathrm{PM}_{2.5}, \mathrm{NH}_{3}, \mathrm{SO}_{x}, \mathrm{NO}_{x}$, and VOC (individually) on three measures of UK-average surface concentrations of $\mathrm{PM}_{2.5}$ : area weighted; population weighted; and the average for the 45 model grids containing the monitors used to calculate the UK $\mathrm{PM}_{2.5}$ average exposure indicator (AEI). Data are shown for simulations for 2010, and for 2030 under a CLE emission scenario (using 2010 meteorology).

Netherlands, and Germany. The influence of emissions originating from continental Europe is revealed by the gradient of decreasing $\mathrm{PM}_{2.5}$ concentrations away from the continent. An analysis presented in AQEG (2015) also using the EMEP4UK model showed that UK emissions contribute around $55 \%$ of the total $\mathrm{PM}_{2.5}$ in the UK. This limits the extent to which long-term average concentrations can be reduced by UK action alone.

Figure 4 shows maps of the impacts on 2010 surface $\mathrm{PM}_{2.5}$ for $30 \%$ reductions in UK terrestrial emissions of each of $\mathrm{NH}_{3}, \mathrm{NO}_{x}, \mathrm{SO}_{x}, \mathrm{VOC}$, and primary $\mathrm{PM}_{2.5}$. The effect of these emissions reductions on the three measures of UKaverage surface concentrations of $\mathrm{PM}_{2.5}$ are illustrated in Fig. 5, based on the data given in Table 1. The principal observations from the two figures are that $\mathrm{PM}_{2.5}$ levels in the UK do not show strong responses to UK-only reductions in emissions of individual components and/or precursors of $\mathrm{PM}_{2.5}$, and that the responses are highly geographically variable. The maximum reduction in $\mathrm{PM}_{2.5}$ concentrations (at a $5 \mathrm{~km}$ grid resolution) reaches $\sim 0.6 \mu \mathrm{g} \mathrm{m}^{-3}$ ( $\sim 6 \%$ of the modelled components) in response to a $30 \%$ reduction in UK emissions of individual components, and in most locations the reductions in $\mathrm{PM}_{2.5}$ concentrations are considerably smaller. This again indicates the influence on $\mathrm{PM}_{2.5}$ in the UK (on an annual average basis) from emissions outside of the UK. In the case of the formation of SIA components, it also reflects the non-linearity in the precursor oxidation chemistry and gas-particle phase partitioning that occurs between emission location and receptor location (Harrison et al., 2013; Vieno et al., 2014). 
Table 1. EMEP4UK-modelled estimates of the impact of $30 \%$ UK terrestrial emissions reductions on three measures of UK-average surface concentrations of $\mathrm{PM}_{2.5}\left(\mu \mathrm{g} \mathrm{m}^{-3}\right)$ : (i) the average of the model grids containing the 45 monitors used to calculate the UK PM 2.5 average exposure indicator (AEI), (ii) the population-weighted average, and (iii) the area-weighted (i.e. geographical) average, for 2010 , and for 2030 under a CLE emission scenario (using 2010 meteorology). For context, the modelled reductions in the baselines between 2010 and 2030 CLE for the three measures of UK-average $\mathrm{PM}_{2.5}$ are $2.42,2.24$, and $1.70 \mu \mathrm{g} \mathrm{m}{ }^{-3}$, respectively.

\begin{tabular}{lrrrrrr}
\hline Emissions reduced & \multicolumn{1}{l}{ AEI } & & \multicolumn{2}{c}{ Population-weighted } & \multicolumn{2}{c}{ Area-weighted } \\
& 2010 & 2030 CLE & 2010 & 2030 CLE & 2010 & 2030 CLE \\
\hline Primary $\mathrm{PM}_{2.5}$ & 0.37 & 0.29 & 0.31 & 0.24 & 0.16 & 0.13 \\
$\mathrm{NH}_{3}$ & 0.35 & 0.19 & 0.34 & 0.19 & 0.28 & 0.16 \\
$\mathrm{SO}_{x}$ & 0.27 & 0.15 & 0.26 & 0.15 & 0.19 & 0.11 \\
$\mathrm{NO}_{x}$ & 0.10 & 0.14 & 0.10 & 0.15 & 0.11 & 0.13 \\
VOC & 0.08 & 0.05 & 0.08 & 0.05 & 0.07 & 0.03 \\
\hline Total & 1.17 & 0.82 & 1.10 & 0.77 & 0.82 & 0.57 \\
\hline
\end{tabular}

Figures 4 and 5 show that, on average across the UK, the sensitivity of $\mathrm{PM}_{2.5}$ concentrations to a $30 \%$ reduction in UK emissions of individual contributing components increases in the order VOC, $\mathrm{NO}_{x}, \mathrm{SO}_{x}$, primary $\mathrm{PM}_{2.5}$, and $\mathrm{NH}_{3}$. The exact order varies slightly with the UK-average measure used (Fig. 5). This is due to differences in the spatial patterns of the $\mathrm{PM}_{2.5}$ reductions shown in Fig. 4 in relation to the distribution of UK population shown in Fig. 2.

The $30 \%$ reductions in UK VOC emissions gives maximum reductions of $\sim 0.15 \mu \mathrm{g} \mathrm{m}^{-3}(1.5 \%)$ in $\mathrm{PM}_{2.5}$ concentrations in central and northern England and central Scotland (Fig. 4e). The $30 \%$ reductions in $\mathrm{UK} \mathrm{NO}_{x}$ emissions yield around $0.2 \mu \mathrm{g} \mathrm{m}^{-3}$ (3\%) reductions in $\mathrm{PM}_{2.5}$ over some rural areas (Fig. 4c), and generally a maximum of $0.15 \mu \mathrm{g} \mathrm{m}^{-3}$ $(1.5 \%)$ reductions in $\mathrm{PM}_{2.5}$ over other rural areas. An important observation is that reductions of $\mathrm{PM}_{2.5}$ over urban centres are smaller (no more than $0.15 \mu \mathrm{g} \mathrm{m}^{-3}$ ) than in rural areas for these reductions in $\mathrm{NO}_{x}$ emissions. The $30 \%$ reductions in $\mathrm{UK} \mathrm{SO}_{x}$ emissions yield up to $\sim 0.45-0.5 \mu \mathrm{g} \mathrm{m}^{-3}$ (5\%) reductions in $\mathrm{PM}_{2.5}$ in the Trent valley and up to around $0.3-0.35 \mu \mathrm{g} \mathrm{m}^{-3}$ (3\%) reductions in $\mathrm{PM}_{2.5}$ over large areas of central and northern England and central Scotland (Fig. 4d). The locations with greatest sensitivities to the $30 \%$ $\mathrm{NO}_{x}$ emissions reductions (Fig. $4 \mathrm{c}$ ) are generally those with the lowest sensitivities to $\mathrm{SO}_{x}$ emissions reductions (Fig. 4d). As with the $\mathrm{NO}_{x}$ emissions reductions, the reductions in $\mathrm{PM}_{2.5}$ concentrations for reductions in $\mathrm{SO}_{x}$ emissions is not, in general, associated with the major urban areas, except where these also have major $\mathrm{SO}_{x}$ sources in the vicinity (e.g. Trent Valley, West Midlands, Cheshire). This is primarily caused by the spatial distribution of major sources of $\mathrm{SO}_{x}$ emissions. As $\sim 80 \%$ of $\mathrm{UK} \mathrm{SO}_{x} 2010$ emissions originate from large point sources (power plants, industrial facilities), which are not located in the heart of urban areas, associated emission reductions have the most profound effects in rural areas. However, the greater sensitivity to $\mathrm{SO}_{x}$ close to large point sources (e.g. coal-fired power plants) may in part be an artefact due to the model assumption that $5 \%$ of $\mathrm{SO}_{x}$ emissions are directly in the form of $\mathrm{SO}_{4}^{2-}$, which may no longer be appropriate for these sources or for models running at relatively high horizontal spatial resolution. The $\mathrm{SO}_{x}$ and $\mathrm{NO}_{x}$ gases compete in their reaction with $\mathrm{NH}_{3}$ to form particulate ammonium sulphate $\left(\left(\mathrm{NH}_{4}\right)_{2} \mathrm{SO}_{4}\right)$ or ammonium nitrate $\left(\mathrm{NH}_{4} \mathrm{NO}_{3}\right)$. The larger sensitivity of $\mathrm{PM}_{2.5}$ formation to $\mathrm{NH}_{3}$ emissions reductions indicates that $\mathrm{NH}_{3}$ is the limiting species; whilst the greater sensitivity to $\mathrm{SO}_{x}$ than to $\mathrm{NO}_{x}$ emissions reductions reflects that the reaction between $\mathrm{NH}_{3}$ and $\mathrm{SO}_{x}$ is fast and essentially irreversible compared with the equilibrium reactions between gaseous $\mathrm{NH}_{3}$ and $\mathrm{NO}_{x}$ species and $\mathrm{NH}_{4} \mathrm{NO}_{3}$.

The largest reductions in $\mathrm{PM}_{2.5}$ (when weighted towards areas of greatest population) derive from $30 \%$ reductions in UK $\mathrm{NH}_{3}$ and primary $\mathrm{PM}_{2.5}$ emissions (Fig. $4 \mathrm{~b}$ and f), up to $0.45 \mu \mathrm{g} \mathrm{m}^{-3}$ for $\mathrm{NH}_{3}$ reductions and greater for primary $\mathrm{PM}_{2.5}$ reductions (up to $\sim 6 \%$ of modelled $\mathrm{PM}_{2.5}$ in both cases). There is a distinct inverse geographic relationship in the $\mathrm{PM}_{2.5}$ sensitivity to reductions of these two components. The reductions in $\mathrm{NH}_{3}$ emissions give greatest $\mathrm{PM}_{2.5}$ decreases in agricultural areas, whereas the reductions in primary $\mathrm{PM}_{2.5}$ give greatest decreases in the large conurbations and other areas of high population density. The difference in geographical patterns is highlighted more clearly in Fig. 6a which shows the data in Fig. $4 \mathrm{~b}$ minus the data in Fig. 4f. Blue colours in Fig. 6a indicate where reductions in $\mathrm{PM}_{2.5}$ from a $30 \%$ reduction in $\mathrm{NH}_{3}$ emissions exceed the reductions in $\mathrm{PM}_{2.5}$ from a $30 \%$ reduction in primary $\mathrm{PM}_{2.5}$ emissions, and vice-versa for red colours. White colours indicate comparable reductions in $\mathrm{PM}_{2.5}$ via primary $\mathrm{PM}_{2.5}$ or $\mathrm{NH}_{3}$ emissions reductions. The geographical pattern in $\mathrm{PM}_{2.5}$ sensitivity reflects the geographical pattern of the emission sources and the fact that, because of the short atmospheric lifetime of $\mathrm{NH}_{3}$, UK emissions of $\mathrm{NH}_{3}$ also generally have short-range influence.

Figure 7 shows the map of annual-average surface concentration of $\mathrm{PM}_{2.5}$ estimated for the 2030 CLE emissions projections, and of the difference between the $\mathrm{PM}_{2.5}$ concen- 


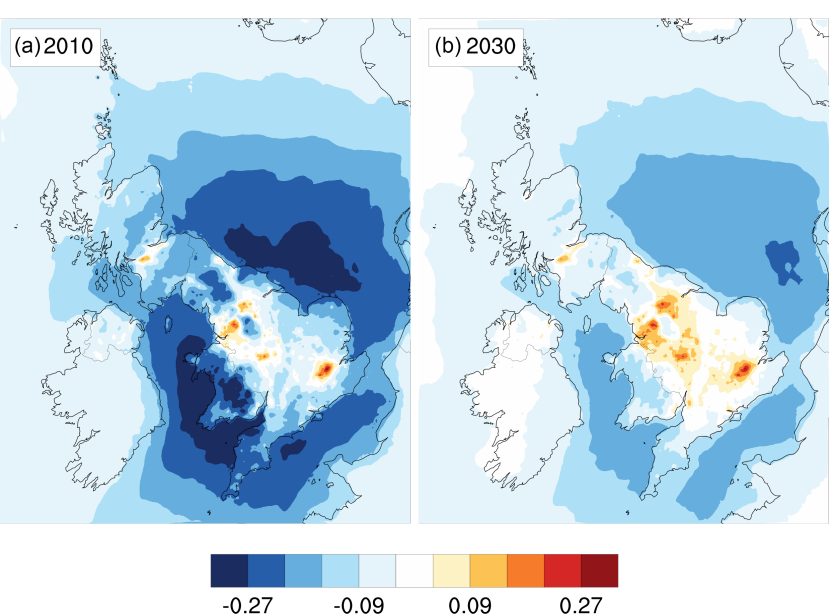

Figure 6. The difference between changes in simulated annualaverage $\mathrm{PM}_{2.5}\left(\mu \mathrm{g} \mathrm{m}^{-3}\right)$ for $30 \%$ reductions in $\mathrm{UK} \mathrm{NH}_{3}$ emissions reduction and for $30 \%$ reductions in UK primary $\mathrm{PM}_{2.5}$ emissions reduction: (a) for the year 2010 (i.e. the data in Fig. 4b minus the data in Fig. 4f); and (b) for the year 2030 (i.e. the data in Figure 8b minus the data in Fig. 8f). Blue colours indicate where reductions in $\mathrm{PM}_{2.5}$ for $30 \%$ reduction in $\mathrm{NH}_{3}$ emissions exceed the reductions in $\mathrm{PM}_{2.5}$ for $30 \%$ reduction in primary $\mathrm{PM}_{2.5}$ emissions, and vice versa for the red colours. The same meteorological year 2010 was used.

trations in 2030 and 2010. Surface concentrations of $\mathrm{PM}_{2.5}$ over the UK are simulated to reduce by up to $2.8 \mu \mathrm{g} \mathrm{m}^{-3}$ between 2010 and the 2030 CLE emissions scenario used. The UK-wide reductions in $\mathrm{PM}_{2.5}$ between 2010 and 2030 CLE are $1.70,2.24$, and $2.42 \mu \mathrm{g} \mathrm{m}^{-3}$ for the area-weighted, population-weighted and AEI summary measures, respectively. The impacts on surface $\mathrm{PM}_{2.5}$ in 2030 of additional $30 \%$ reductions applied to UK-only terrestrial emissions of each of $\mathrm{NH}_{3}, \mathrm{NO}_{x}, \mathrm{SO}_{x}$, VOC, and primary $\mathrm{PM}_{2.5}$ individually are shown in Fig. 8. Figure 5 illustrates the quantitative effect of these further emissions reductions against the 2030 CLE scenario on the three summary measures of UK-average surface concentrations of $\mathrm{PM}_{2.5}$.

The maps in Fig. 8 show qualitatively very similar findings to their equivalent maps in Fig. 4. In 2030, UK PM 2.5 is projected to remain more sensitive to reductions in UK emissions of $\mathrm{NH}_{3}$ and primary $\mathrm{PM}_{2.5}$ than to reductions in $\mathrm{UK} \mathrm{SO}_{x}$ and $\mathrm{NO}_{x}$; and, from a population-weighted perspective, to be relatively more sensitive to further primary $\mathrm{PM}_{2.5}$ and $\mathrm{NH}_{3}$ emissions reductions, particularly to primary $\mathrm{PM}_{2.5}$ emissions reductions, than was the case for the 2010 simulations (Fig. 5). For the 2030 simulations, additional $30 \%$ reductions in UK primary $\mathrm{PM}_{2.5}$ or $\mathrm{NH}_{3}$ emissions yield reductions in $\mathrm{PM}_{2.5}$ of up to 0.5 or $0.25 \mu \mathrm{g} \mathrm{m}^{-3}$, respectively (Fig. 8), whilst in 2010 additional $30 \%$ reductions in primary $\mathrm{PM}_{2.5}$ or $\mathrm{NH}_{3}$ emissions yield reductions in $\mathrm{PM}_{2.5}$ of up to 0.6 or $0.45 \mu \mathrm{g} \mathrm{m}^{-3}$, respectively (Fig. 4). The 2030 results again emphasize a geographic pattern of greatest sensitivity

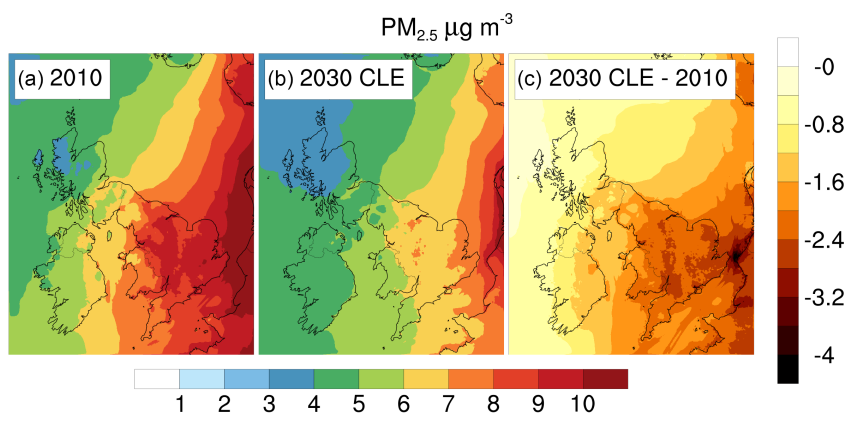

Figure 7. EMEP4UK annual-average surface concentration of $\mathrm{PM}_{2.5}\left(\mu \mathrm{g} \mathrm{m}^{-3}\right)$ for (a) 2010 emissions, and (b) 2030 CLE emissions projection (bottom colour scale), and (c) the difference 2030 CLE - 2010 CLE (right colour scale). The same meteorological year 2010 was used.

of $\mathrm{PM}_{2.5}$ to reductions in the areas of high population density. Figure $6 \mathrm{~b}$ plots the difference in response to the $\mathrm{NH}_{3}$ and primary $\mathrm{PM}_{2.5}$ emissions reductions in 2030 , analogous to the plot in Fig. 6a for the 2010 sensitivities. Figure 6b clearly emphasizes that for this projection for 2030 , UK $\mathrm{PM}_{2.5}$ is relatively even more sensitive to further reductions in UK primary $\mathrm{PM}_{2.5}$ emissions compared with further reductions in $\mathrm{UK} \mathrm{NH}_{3}$ emissions, particularly in populated areas, than is the case for 2010; albeit that the additional absolute reductions in $\mathrm{PM}_{2.5}$ for a given percentage of emissions reductions is smaller in 2030 than in 2010 (Fig. 5) because of the general decline in emissions across Europe during this period for this scenario.

\section{Discussion}

Simulations were undertaken for both 2010 and a 2030 scenario to investigate whether conclusions on effectiveness of potential UK mitigation differ between the two time points. It is recognized that reductions in emissions of primary $\mathrm{PM}_{2.5}$ and precursor gases from many anthropogenic sources are already anticipated going forward under current legislation, so it is important to know, for a future policy perspective, the anticipated sensitivities of UK $\mathrm{PM}_{2.5}$ to additional UK emission reductions in the future.

The simulations for both 2010 and 2030 CLE show that if the focus is on the reduction of spatially averaged $\mathrm{PM}_{2.5}$ concentrations then the most effective UK control, via an individual component, is achieved through reduction of UK emissions of $\mathrm{NH}_{3}$, as shown in Fig. 5. However, the conclusion is different when considering population-weighted $\mathrm{PM}_{2.5}$ reductions for the mitigation of human health effects. For a full population weighting across all $5 \mathrm{~km} \times 5 \mathrm{~km}$ model grids, reductions in UK primary $\mathrm{PM}_{2.5}$ emissions are almost as effective as reductions in $\mathrm{UK} \mathrm{NH}_{3}$ emissions for the 2010 simulations, but primary $\mathrm{PM}_{2.5}$ emissions reductions are simulated to be the most effective additional control in the 


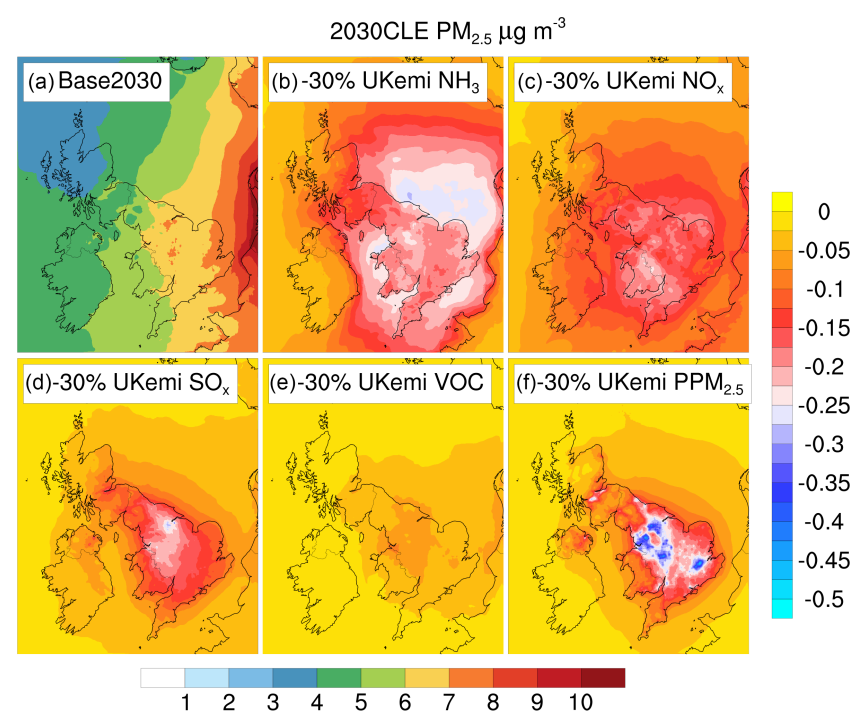

Figure 8. Model simulations of impact of $30 \%$ UK emissions reductions on annual-average surface concentration of $\mathrm{PM}_{2.5}$ for a future scenario (with 2010 meteorology). Panel (a), 2030 CLE scenario, no emissions reduction (bottom colour scale); remaining panels, the change in annual-average $\mathrm{PM}_{2.5}$ for $30 \% \mathrm{UK}$ emissions reductions in (b) $\mathrm{NH}_{3}$, (c) $\mathrm{NO}_{x}$, (d) $\mathrm{SO}_{x}$, (e) VOC, and (f) primary $\mathrm{PM}_{2.5}$ (right colour scale). All units are $\mu \mathrm{g} \mathrm{m}^{-3}$.

2030 CLE future (Fig. 5). Emphasis on population weighting also increases the sensitivities of $\mathrm{PM}_{2.5}$ to reductions in $\mathrm{NO}_{x}$ emissions in both 2010 and 2030 CLE because a major source of $\mathrm{NO}_{x}$ is road traffic whose emissions are associated with where the population live. On the other hand, the sensitivity of $\mathrm{PM}_{2.5}$ to further reductions in $\mathrm{UK} \mathrm{SO}_{x}$ emissions is markedly lower in 2030 than in 2010 because of the large reductions in $\mathrm{SO}_{x}$ emissions already implemented under the CLE scenario. It is also recognized that reductions in $\mathrm{NO}_{x}$ and VOC emissions have the potential to deliver health benefits separately from their contribution to reduction in $\mathrm{PM}_{2.5}$ through reductions in population exposure to surface $\mathrm{NO}_{2}$ and $\mathrm{O}_{3}$.

An important observation is that the effectiveness of emissions reductions on $\mathrm{PM}_{2.5}$ using a population weighting for the quantification differs between evaluation via full nationwide gridded population-weighting or via use of data only at the locations used to derive the AEI. Quantification through the AEI puts greater emphasis on the effectiveness of primary $\mathrm{PM}_{2.5}$ emissions reduction, and on $\mathrm{NO}_{x}$ emissions reductions, (Fig. 5) because the monitor locations contributing to the AEI are sited in the largest cities and towns where emissions of primary $\mathrm{PM}_{2.5}$ and $\mathrm{NO}_{x}$ are prevalent. Based on the AEI, control of primary $\mathrm{PM}_{2.5}$ is the most effective individual component in 2010 as well as in 2030 CLE. These observations are pertinent given that the AEI is the air quality metric for $\mathrm{PM}_{2.5}$.
Analyses from the EUCAARI study in Kulmala et al. (2011) and a more recent European study in Megaritis et al. (2013) both suggest that reducing $\mathrm{NH}_{3}$ emissions is the most effective way to reduce $\mathrm{PM}_{2.5}$ under present-day conditions. Whilst the current study also emphasizes the sensitivity of $\mathrm{PM}_{2.5}$ to $\mathrm{NH}_{3}$ emissions reductions, it also emphasizes that, for the UK, a sensitivity to primary $\mathrm{PM}_{2.5}$ emissions reductions is at least as great as for $\mathrm{NH}_{3}$ when considering population-weighting of $\mathrm{PM}_{2.5}$ concentrations, both currently and for a future CLE scenario. In fact the sensitivity to primary $\mathrm{PM}_{2.5}$ emissions may be underestimated by the simulations because of dilution of primary $\mathrm{PM}_{2.5}$ emissions into the $5 \mathrm{~km} \times 5 \mathrm{~km}$ grid resolution of the model. It has been calculated that a $1: 1$ relationship between UK primary $\mathrm{PM}_{2.5}$ emissions reductions and the reduction in the primary $\mathrm{PM}_{2.5}$ component of the UK 2010 AEI would lead to a reduction in the 2010 AEI of $0.8 \mu \mathrm{g} \mathrm{m}^{-3}$ (AQEG, 2015), compared with the $0.37 \mu \mathrm{g} \mathrm{m}^{-3}$ derived from the model simulations in this work (Table 1). Even so, the total impact of $30 \%$ reductions in UK emissions of all the components and/or precursors listed in Table 1 on the 2010 baseline, is only of comparable magnitude $\left(1.2 \mu \mathrm{g} \mathrm{m}^{-3}\right.$ ) to the $15 \%$ (or $1.3 \mu \mathrm{g} \mathrm{m}^{-3}$ ) reduction required in the UK AEI by 2020 . However, reductions in these emissions from outside the UK will also contribute to reducing the $\mathrm{UK} \mathrm{PM}_{2.5}$ AEI. Conversely, reductions of emissions in the UK will also yield benefits for surface $\mathrm{PM}_{2.5}$ concentrations elsewhere in Europe. The country-to-country source-receptor matrices developed by EMEP MSC-W at the $50 \mathrm{~km}$ resolution indicate that reductions in the UK of the same primary and precursor species considered in this work would (for 2011 emissions) lead to reductions in $\mathrm{PM}_{2.5}$ in neighbouring countries up to about one-third the magnitude of the $\mathrm{PM}_{2.5}$ reductions in the UK (Fagerli et al., 2014). Reductions of emissions in the UK would also lead to other benefits outside the $\mathrm{UK}$ on, for example, $\mathrm{NO}_{2}$ and $\mathrm{O}_{3}$ exposure and on $\mathrm{N}$ and $\mathrm{S}$ deposition.

Although the model used in this study is widely applied across Europe for air quality policy development (Fagerli et al., 2014), the data presented here are from simulations from a single model. The model simulations of the effect of inorganic precursor gases on the secondary inorganic $\mathrm{PM}_{2.5}$ are dependent on accurate representation of the relevant chemistry and phase partitioning. It is possible that the SIA representation in the EMEP4UK model may underestimate the nitrate in the $\mathrm{PM}_{2.5}$ size fraction, and hence downplay somewhat the sensitivity of $\mathrm{PM}_{2.5}$ to $\mathrm{NO}_{x}$ emissions reductions. In addition, not explicitly calculating the uptake of $\mathrm{HNO}_{3}$ by mineral dust may reduce the $\mathrm{NO}_{3}^{-}$changes due to $\mathrm{NO}_{x}$ emissions reduction. However, the EMEP4UK particle sulphate, nitrate and ammonium concentrations all compare well with the multi-year time series of measurements of these components at $\sim 30$ sites across the UK in the Acid Gas and Aerosol Network (AGANet) and National Ammonia Monitoring Network (NAMN) (Vieno et al., 2014). Variation in particlebound water may also impact on the exact $\mathrm{PM}_{2.5}$ mass sen- 
sitivities associated with inorganic precursor gas emissions reductions.

Inter-annual variability in meteorology may also have an influence, in particular in determining the balance in any year between $\mathrm{PM}_{2.5}$ in the UK derived from UK emissions and that derived from emissions outside the UK (Vieno et al., 2014). However, whilst the precise quantitative sensitivities of annual average $\mathrm{PM}_{2.5}$ to emissions reductions will be subject to inter-annual meteorological variability, it is anticipated that the broad findings of this study will hold.

The interpretation of the modelling results has been undertaken from the perspective that reduction in all anthropogenically derived components of $\mathrm{PM}_{2.5}$ is equally important. This remains the current position for the EU legislation that sets limits and targets for concentrations of $\mathrm{PM}_{2.5}$ (Heal et al., 2012); i.e. no consideration is given to the potential different toxicity to human health of different components of $\mathrm{PM}_{2.5}$. The UK Committee on the Medical Effects of Air Pollutants has also recently concluded that reductions in concentrations of both primary and secondary particles are likely to benefit public health (COMEAP, 2015). Nevertheless, although not conclusive, there is evidence that traffic-related sources of PM, or combustion sources more generally, are particularly associated with adverse health outcomes (Grahame and Schlesinger, 2007, 2010; Janssen et al., 2011; Stanek et al., 2011; WHO, 2013; Grahame et al., 2014). The possibility that primary $\mathrm{PM}_{2.5}$ is more toxic per unit mass than secondary $\mathrm{PM}_{2.5}$, places greater emphasis on the finding from this work on the effectiveness of reductions in emissions of primary $\mathrm{PM}_{2.5}$. Interpretation of the modelling results has also not considered the relative costs or feasibilities of implementing further reductions in the emissions of the individual precursors and components investigated.

Finally, it should be remembered that measures taken in the UK to reduce concentrations of ambient $\mathrm{PM}_{2.5}$ and of precursor gases, both within and outside of populated areas, will have multiple co-benefits on human health, $\mathrm{N}$ and $\mathrm{S}$ deposition, ozone formation and radiative forcing, not just in the UK but elsewhere.

\section{Conclusions}

The sensitivity of annual-average surface concentrations of $\mathrm{PM}_{2.5}$ across the UK to reductions in UK terrestrial anthropogenic emissions in primary $\mathrm{PM}_{2.5}, \mathrm{NH}_{3}, \mathrm{NO}_{x}, \mathrm{SO}_{x}$, and non-methane VOC was investigated using the EMEP4UK atmospheric chemistry transport model for 2010 and for a 2030 current legislation scenario that includes projected pan-European emission changes. In general, the sensitivity of modelled concentrations to UK-only mitigation is rather small. A $30 \%$ reduction in UK emissions of any one of the above listed PM components yields (for the 2010 simulation) a maximum reduction in $\mathrm{PM}_{2.5}$ concentrations in any given location of $\sim 0.6 \mathrm{\mu g} \mathrm{m}^{-3}$ (equivalent to $\sim 6 \%$ of the total modelled $\mathrm{PM}_{2.5}$ mass concentration). On average across the UK, the sensitivity of $\mathrm{PM}_{2.5}$ concentrations to a $30 \%$ reduction in UK emissions of individual contributing components, for both the 2010 and 2030 CLE baselines, increases in the order $\mathrm{NMVOC}, \mathrm{NO}_{x}, \mathrm{SO}_{x}, \mathrm{NH}_{3}$, and primary $\mathrm{PM}_{2.5}$, but there are strong spatial differences in the $\mathrm{PM}_{2.5}$ sensitivities across the UK. Consequently, the sensitivity of $\mathrm{PM}_{2.5}$ to individual component emissions reductions varies between area and population weighting. Reductions in $\mathrm{NH}_{3}$ have the greatest area-weighted effect on $\mathrm{PM}_{2.5}$. A full UK population weighting places greater emphasis on reductions of primary $\mathrm{PM}_{2.5}$ emissions, which is simulated to be the most effective single-component control on $\mathrm{PM}_{2.5}$ for the 2030 scenario. An important observation is that weighting corresponding to the average exposure indicator metric (using data from the 45 model grids containing a monitor whose measurements are used to calculate the UK AEI) further increases the emphasis on the effectiveness of primary $\mathrm{PM}_{2.5}$ emissions reductions (and of $\mathrm{NO}_{x}$ emissions reductions) relative to the effectiveness of $\mathrm{NH}_{3}$ emissions reductions. Reductions in primary $\mathrm{PM}_{2.5}$ has the largest impact on the AEI in 2010 as well as the 2030 CLE scenario. The summation of the reductions to the UK $\mathrm{PM}_{2.5} \mathrm{AEI}$ of the $30 \%$ reductions in UK emissions of primary $\mathrm{PM}_{2.5}$ and of $\mathrm{NH}_{3}, \mathrm{SO}_{x}, \mathrm{NO}_{x}$ and VOC totals $\sim 1.2$ and $\sim 0.8 \mu \mathrm{g} \mathrm{m}^{-3}$ with respect to the 2010 and 2030 CLE baselines, respectively (not accounting for non-linearity).

Acknowledgements. This work is funded jointly by the UK Department for the Environment, Food and Rural Affairs (Defra), the NERC Centre for Ecology and Hydrology (CEH), the EMEP programme under the United Nations Economic Commission for Europe Convention on Long-range Transboundary Air Pollution, the Norwegian Meteorological Institute (Met.No) and the European Union projects; NitroEurope IP and ÉCLAIRE.

Edited by: J. G. Murphy

\section{References}

Aas, W., Tsyro, S., Bieber, E., Bergström, R., Ceburnis, D., Ellermann, T., Fagerli, H., Frölich, M., Gehrig, R., Makkonen, U., Nemitz, E., Otjes, R., Perez, N., Perrino, C., Prévôt, A. S. H., Putaud, J.-P., Simpson, D., Spindler, G., Vana, M., and Yttri, K. E.: Lessons learnt from the first EMEP intensive measurement periods, Atmos. Chem. Phys., 12, 8073-8094, doi:10.5194/acp12-8073-2012, 2012.

AQEG: Mitigation of United Kingdom $\mathrm{PM}_{2.5}$ Concentrations, Air Quality Expert Group, UK Department for Environment, Food and Rural Affairs, London, PB13837, available at: http://uk-air.defra.gov.uk/assets/documents/reports/cat11/ 1508060903_DEF-PB14161_Mitigation_of_UK_PM25.pdf, last access: 1 November 2015.

Brookes, D. M., Stedman, J. R., Kent, A. J., King, R. J., Venfield, H. L., Cooke, S. L., Lingard, J. J. N., Vincent, K. J., Bush, T. J., and Abbott, J.: Technical report on UK supplementary assessment 
under the Air Quality Directive (2008/50/EC), the Air Quality Framework Directive (96/62/EC) and Fourth Daughter Directive (2004/107/EC) for 2011., Prepared by Ricardo-AEA for the UK Department for Environment, Food and Rural Affairs, London, AEAT/ENV/R/3316, 2012.

Carslaw, D. C.: Report: Defra deposition model evaluation analysis - Phase 1, London, available at: http://uk-air.defra.gov.uk/ library/reports?report_id=652 (last access: 1 April 2015), 2011a.

Carslaw, D. C.: Report: Defra regional and transboundary model evaluation analysis - Phase 1, London, available at: http: //uk-air.defra.gov.uk/library/reports?report_id=653, last access: 1 April 2015, 2011b.

Coleman, L., Martin, D., Varghese, S., Jennings, S. G., and O'Dowd, C. D.: Assessment of changing meteorology and emissions on air quality using a regional climate model: Impact on ozone, Atmos. Environ., 69, 198-210, doi:10.1016/j.atmosenv.2012.11.048, 2013.

Colette, A., Bessagnet, B., Vautard, R., Szopa, S., Rao, S., Schucht, S., Klimont, Z., Menut, L., Clain, G., Meleux, F., Curci, G., and Rouïl, L.: European atmosphere in 2050, a regional air quality and climate perspective under CMIP5 scenarios, Atmos. Chem. Phys., 13, 7451-7471, doi:10.5194/acp-13-7451-2013, 2013.

COMEAP: The mortality effects of long-term exposure to particulate air pollution in the United Kingdom, Department of Health Committee on the Medical Effects of Air Pollution, Chilton, ISBN 978-0-85951-685-3, available at: http://comeap. org.uk/documents/reports.html (last access: 1 December 2014), 2010.

COMEAP: Statement on the evidence for differential health effects of particulate matter according to source or components, UK Department of Health Committee on the Medical Effects of Air Pollutants, Chilton, available at: https://www.gov.uk/government/publications/ particulate-air-pollution-health-effects-of-exposure, last access: 1 March 2015.

Conolly, C., Lawrence, H., Vincent, K., Donovan, B., Davies, M., Colbeck, C., Cape, J. N., Tang, Y. S., Bealey, W. J., Leaver, D., Poskitt, J., Beith, S., Thacker, S., Hockenhull, K., Woods, C., Simmons, I., Braban, C. F., van Dyke, N., Rowland, P., Fowler, D., and Sutton, M. A.: UK Eutrophying and Acidifying Atmospheric Pollutants (UKEAP) Annual Report 2010, available at: http://uk-air.defra.gov.uk/library/reports?report_id=651 (last access: 1 April 2015), Defra, London, 2011.

DECC: Department of Energy and Climate Change (DECC), available at: https://www.gov.uk/government/collections/ energy-and-emissions-projections, last access: 20 June 2015.

Defra: Air Pollution in the UK 2011, Department for Environment, available at: http://uk-air.defra.gov.uk/assets/documents/ annualreport/air_pollution_uk_2011_issue_2.pdf (last access: 1 December 2014), Department for Environment Food and Rural Affairs, London, 2012.

EEA: Air quality in Europe - 2014 report. EEA Report No 5/2014., European Environment Agency, Publications Office of the European Union, available at: http://www.eea.europa.eu/publications/ air-quality-in-europe-2014 last access: 1 January 2014.

ENTEC: Defra, UK ship emissions inventory, final report, available at: http://uk-air.defra.gov.uk/reports/cat15/1012131459_21897_ Final_Report_291110.pdf (last access: 1 December 2015), Crown copyright, 2010.
Fagerli, H., Schulz, M., Gauss, M., Tsyro, S., Jonson, J. E., Benedictow, A., Simpson, D., Valdebenito, Á., Griesfeller, J., Semeena, V. S., Wind, P., Olivié, D., Aas, W., Hamburger, D., Hjellbrekke, A. G., Solberg, S., Torseth, K., Yttri, K. E., Karl, M., Mareckova, K., Wankmüller, R., Alastuey, A., Posch, M., and Tuovinen, J. P.: Transboundary particulate matter, photo-oxidants, acidifying and eutrophying components, EMEP Status Report 2014; ISSN 1504-6109, 29 August 2014.

Grahame, T. J. and Schlesinger, R. B.: Health effects of airborne particulate matter: Do we know enough to consider regulating specific particle types or sources?, Inhal. Toxicol., 19, 457-481, 2007.

Grahame, T. J. and Schlesinger, R. B.: Cardiovascular health and particulate vehicular emissions: a critical evaluation of the evidence, Air Qual. Atmos. Hlth., 3, 3-27, doi:10.1007/s11869009-0047-x, 2010.

Grahame, T. J., Klemm, R., and Schlesinger, R. B.: Public health and components of particulate matter: The changing assessment of black carbon, J. Air Waste. Manage., 64, 620-660, doi:10.1080/10962247.2014.912692, 2014.

Harrison, R. M., Jones, A. M., Beddows, D. C. S., and Derwent, R. G.: The effect of varying primary emissions on the concentrations of inorganic aerosols predicted by the enhanced UK Photochemical Trajectory Model, Atmos. Environ., 69, 211-218, doi:10.1016/j.atmosenv.2012.12.016, 2013.

Heal, M. R., Kumar, P., and Harrison, R. M.: Particles, air quality, policy and health, Chem. Soc. Rev., 41, 6606-6630, doi:10.1039/C2cs35076a, 2012.

IIASA: Future emissions of air pollutants in Europe - Current legislation baseline and the scope for further reductions, available at: http://ec.europa.eu/environment/air/pdf/ TSAP-BASELINE-20120613[1].pdf (last access: 1 December 2014), 2012.

IPCC: Climate Change 2013: The Physical Science Basis. Contribution of Working Group I to the Fifth Assessment Report of the Intergovernmental Panel on Climate Change, Cambridge University Press, Cambridge, United Kingdom and New York, NY, USA, 1535 pp., 2013.

Janssen, N. A. H., Hoek, G., Simic-Lawson, M., Fischer, P., van Bree, L., ten Brink, H., Keuken, M., Atkinson, R. W., Anderson, H. R., Brunekreef, B., and Cassee, F. R.: Black Carbon as an Additional Indicator of the Adverse Health Effects of Airborne Particles Compared with $\mathrm{PM}_{10}$ and $\mathrm{PM}_{2.5}$, Environ. Health Persp., 119, 1691-1699, doi:10.1289/Ehp.1003369, 2011.

Kulmala, M., Asmi, A., Lappalainen, H. K., Baltensperger, U., Brenguier, J.-L., Facchini, M. C., Hansson, H.-C., Hov, Ø., O'Dowd, C. D., Pöschl, U., Wiedensohler, A., Boers, R., Boucher, O., de Leeuw, G., Denier van der Gon, H. A. C., Feichter, J., Krejci, R., Laj, P., Lihavainen, H., Lohmann, U., McFiggans, G., Mentel, T., Pilinis, C., Riipinen, I., Schulz, M., Stohl, A., Swietlicki, E., Vignati, E., Alves, C., Amann, M., Ammann, M., Arabas, S., Artaxo, P., Baars, H., Beddows, D. C. S., Bergström, R., Beukes, J. P., Bilde, M., Burkhart, J. F., Canonaco, F., Clegg, S. L., Coe, H., Crumeyrolle, S., D’Anna, B., Decesari, S., Gilardoni, S., Fischer, M., Fjaeraa, A. M., Fountoukis, C., George, C., Gomes, L., Halloran, P., Hamburger, T., Harrison, R. M., Herrmann, H., Hoffmann, T., Hoose, C., Hu, M., Hyvärinen, A., Hõrrak, U., Iinuma, Y., Iversen, T., Josipovic, M., Kanakidou, M., Kiendler-Scharr, A., Kirkevåg, A., Kiss, G., 
Klimont, Z., Kolmonen, P., Komppula, M., Kristjánsson, J.-E., Laakso, L., Laaksonen, A., Labonnote, L., Lanz, V. A., Lehtinen, K. E. J., Rizzo, L. V., Makkonen, R., Manninen, H. E., McMeeking, G., Merikanto, J., Minikin, A., Mirme, S., Morgan, W. T., Nemitz, E., O’Donnell, D., Panwar, T. S., Pawlowska, H., Petzold, A., Pienaar, J. J., Pio, C., Plass-Duelmer, C., Prévôt, A. S. H., Pryor, S., Reddington, C. L., Roberts, G., Rosenfeld, D., Schwarz, J., Seland, Ø., Sellegri, K., Shen, X. J., Shiraiwa, M., Siebert, H., Sierau, B., Simpson, D., Sun, J. Y., Topping, D., Tunved, P., Vaattovaara, P., Vakkari, V., Veefkind, J. P., Visschedijk, A., Vuollekoski, H., Vuolo, R., Wehner, B., Wildt, J., Woodward, S., Worsnop, D. R., van Zadelhoff, G.-J., Zardini, A. A., Zhang, K., van Zyl, P. G., Kerminen, V.-M., S Carslaw, K., and Pandis, S. N.: General overview: European Integrated project on Aerosol Cloud Climate and Air Quality interactions (EUCAARI) - integrating aerosol research from nano to global scales, Atmos. Chem. Phys., 11, 13061-13143, doi:10.5194/acp11-13061-2011, 2011.

Langner, J., Engardt, M., Baklanov, A., Christensen, J. H., Gauss, M., Geels, C., Hedegaard, G. B., Nuterman, R., Simpson, D., Soares, J., Sofiev, M., Wind, P., and Zakey, A.: A multi-model study of impacts of climate change on surface ozone in Europe, Atmos. Chem. Phys., 12, 10423-10440, doi:10.5194/acp12-10423-2012, 2012.

Lim, S. S., Vos, T., Flaxman, A. D., Danaei, G., Shibuya, K., Adair-Rohani, H., Amann, M., Anderson, H. R., Andrews, K. G., Aryee, M., Atkinson, C., Bacchus, L. J., Bahalim, A. N., Balakrishnan, K., Balmes, J., Barker-Collo, S., Baxter, A., Bell, M. L., Blore, J. D., Blyth, F., Bonner, C., Borges, G., Bourne, R., Boussinesq, M., Brauer, M., Brooks, P., Bruce, N. G., Brunekreef, B., Bryan-Hancock, C., Bucello, C., Buchbinder, R., Bull, F., Burnett, R. T., Byers, T. E., Calabria, B., Carapetis, J., Carnahan, E., Chafe, Z., Charlson, F., Chen, H. L., Chen, J. S., Cheng, A. T. A., Child, J. C., Cohen, A., Colson, K. E., Cowie, B. C., Darby, S., Darling, S., Davis, A., Degenhardt, L., Dentener, F., Des Jarlais, D. C., Devries, K., Dherani, M., Ding, E. L., Dorsey, E. R., Driscoll, T., Edmond, K., Ali, S. E., Engell, R. E., Erwin, P. J., Fahimi, S., Falder, G., Farzadfar, F., Ferrari, A., Finucane, M. M., Flaxman, S., Fowkes, F. G. R., Freedman, G., Freeman, M. K., Gakidou, E., Ghosh, S., Giovannucci, E., Gmel, G., Graham, K., Grainger, R., Grant, B., Gunnell, D., Gutierrez, H. R., Hall, W., Hoek, H. W., Hogan, A., Hosgood, H. D., Hoy, D., Hu, H., Hubbell, B. J., Hutchings, S. J., Ibeanusi, S. E., Jacklyn, G. L., Jasrasaria, R., Jonas, J. B., Kan, H. D., Kanis, J. A., Kassebaum, N., Kawakami, N., Khang, Y. H., Khatibzadeh, S., Khoo, J. P., Kok, C., Laden, F., Lalloo, R., Lan, Q., Lathlean, T., Leasher, J. L., Leigh, J., Li, Y., Lin, J. K., Lipshultz, S. E., London, S., Lozano, R., Lu, Y., Mak, J., Malekzadeh, R., Mallinger, L., Marcenes, W., March, L., Marks, R., Martin, R., McGale, P., McGrath, J., Mehta, S., Mensah, G. A., Merriman, T. R., Micha, R., Michaud, C., Mishra, V., Hanafiah, K. M., Mokdad, A. A., Morawska, L., Mozaffarian, D., Murphy, T., Naghavi, M., Neal, B., Nelson, P. K., Nolla, J. M., Norman, R., Olives, C., Omer, S. B., Orchard, J., Osborne, R., Ostro, B., Page, A., Pandey, K. D., Parry, C. D. H., Passmore, E., Patra, J., Pearce, N., Pelizzari, P. M., Petzold, M., Phillips, M. R., Pope, D., Pope, C. A., Powles, J., Rao, M., Razavi, H., Rehfuess, E. A., Rehm, J. T., Ritz, B., Rivara, F. P., Roberts, T., Robinson, C., Rodriguez-Portales, J. A., Romieu, I., Room, R., Rosenfeld, L. C., Roy, A., Rushton, L., Sa- lomon, J. A., Sampson, U., Sanchez-Riera, L., Sanman, E., Sapkota, A., Seedat, S., Shi, P. L., Shield, K., Shivakoti, R., Singh, G. M., Sleet, D. A., Smith, E., Smith, K. R., Stapelberg, N. J. C., Steenland, K., Stockl, H., Stovner, L. J., Straif, K., Straney, L., Thurston, G. D., Tran, J. H., Van Dingenen, R., van Donkelaar, A., Veerman, J. L., Vijayakumar, L., Weintraub, R., Weissman, M. M., White, R. A., Whiteford, H., Wiersma, S. T., Wilkinson, J. D., Williams, H. C., Williams, W., Wilson, N., Woolf, A. D., Yip, P., Zielinski, J. M., Lopez, A. D., Murray, C. J. L., and Ezzati, M.: A comparative risk assessment of burden of disease and injury attributable to 67 risk factors and risk factor clusters in 21 regions, 1990-2010: a systematic analysis for the Global Burden of Disease Study 2010, Lancet, 380, 2224-2260, 2012.

Megaritis, A. G., Fountoukis, C., Charalampidis, P. E., Pilinis, C., and Pandis, S. N.: Response of fine particulate matter concentrations to changes of emissions and temperature in Europe, Atmos. Chem. Phys., 13, 3423-3443, doi:10.5194/acp-13-34232013, 2013.

Schaap, M., Cuvelier, C., Hendriks, C., Bessagnet, B., Baldasano, J. M., Colette, A., Thunis, P., Karam, D., Fagerli, H., Graff, A., Kranenburg, R., Nyiri, A., Pay, M. T., Rouïl, L., Schulz, M., Simpson, D., Stern, R., Terrenoire, E., and Wind, P.: Performance of European chemistry transport models as function of horizontal resolution, Atmos. Environ., 112, 90-105, doi:10.1016/j.atmosenv.2015.04.003, 2015.

Schulz, M., Gauss, M., Benedictow, A., Jonson, J. E., Tsyro, S., Nyıri, A., Simpson, D., Steensen, B. M., Klein, H., Valdebenito, A., Wind, P., Kirkevaag, A., Griesfeller, J., Bartnicki., J., Olivie, D., Grini, A., Iversen, T., Seland, Ø., Semeena, V. S., Fagerli, F., Aas, W., Hjellbrekke, A., Mareckova, K., Wankmuller, R., Schneider, P., Solberg, S., Svendby, T., Liu, L., Posch, M., Vieno, M., Reis, S., Kryza, M., Werner, M., and Walaszek, K.: Transboundary Acidification, Eutrophication and Ground Level Ozone in Europe in 2011, EMEP Status Report 2013; ISSN 1504-6109, 7 August 2013.

Simpson, D., Benedictow, A., Berge, H., Bergström, R., Emberson, L. D., Fagerli, H., Flechard, C. R., Hayman, G. D., Gauss, M., Jonson, J. E., Jenkin, M. E., Nyíri, A., Richter, C., Semeena, V. S., Tsyro, S., Tuovinen, J.-P., Valdebenito, Á., and Wind, P.: The EMEP MSC-W chemical transport model - technical description, Atmos. Chem. Phys., 12, 7825-7865, doi:10.5194/acp-127825-2012, 2012.

Simpson, D., Andersson, C., Christensen, J. H., Engardt, M., Geels, C., Nyiri, A., Posch, M., Soares, J., Sofiev, M., Wind, P., and Langner, J.: Impacts of climate and emission changes on nitrogen deposition in Europe: a multi-model study, Atmos. Chem. Phys., 14, 6995-7017, doi:10.5194/acp-14-6995-2014, 2014.

Stanek, L. W., Brown, J. S., Stanek, J., Gift, J., and Costa, D. L.: Air Pollution Toxicology-A Brief Review of the Role of the Science in Shaping the Current Understanding of Air Pollution Health Risks, Toxicol. Sci., 120, S8-S27, doi:10.1093/toxsci/kfq367, 2011.

USEPA: 2009 Final Report: Integrated Science Assessment for Particulate Matter, U.S. Environmental Protection Agency, Washington, DC, EPA/600/R-08/139F, 2009.

Vieno, M., Dore, A. J., Wind, P., Di Marco, C., Nemitz, E., Phillips, G., Tarrason, L., and Sutton, M. A.: Application of the EMEP Unified Model to the UK with a Horizontal Resolution of $5 \times$ 
$5 \mathrm{~km}^{2}$, in: Atmospheric Ammonia, edited by: Sutton, M., Reis, S., and Baker, S. H., Springer Netherlands, 2009.

Vieno, M., Dore, A. J., Stevenson, D. S., Doherty, R., Heal, M. R., Reis, S., Hallsworth, S., Tarrason, L., Wind, P., Fowler, D., Simpson, D., and Sutton, M. A.: Modelling surface ozone during the 2003 heat-wave in the UK, Atmos. Chem. Phys., 10, 7963-7978, doi:10.5194/acp-10-7963-2010, 2010.

Vieno, M., Heal, M. R., Hallsworth, S., Famulari, D., Doherty, R. M., Dore, A. J., Tang, Y. S., Braban, C. F., Leaver, D., Sutton, M. A., and Reis, S.: The role of long-range transport and domestic emissions in determining atmospheric secondary inorganic particle concentrations across the UK, Atmos. Chem. Phys., 14, 8435-8447, doi:10.5194/acp-14-8435-2014, 2014.
WHO: Air quality guidelines, Global update 2005. Particulate matter, ozone, nitrogen dioxide and sulfur dioxide, World Health Organisation Regional Office for Europe, Copenhagen, available at: http://www.euro.who.int/_data/assets/pdf_file/0005/ 78638/E90038.pdf (last access: 1 January 2015), 2006.

WHO: Review of evidence on health aspects of air pollution - REVIHAAP Project: Technical Report, World Health Organisation, Copenhagen, available at: http://www.euro.who.int/_data/assets/pdf_file/0004/193108/ REVIHAAP-Final-technical-report-final-version.pdf (last access: 1 December 2014), 2013. 